\title{
Multiple Brain Abscesses Secondary to Odontogenic Infection: A Clinical Case Report
}

\section{Abscessos cerebrais múltiplos secundários à infecção odontogênica: Um relato de caso clínico}

\author{
Paulo Lucas Capelini Frisso ${ }^{10}$ Richam Faissal El Hossain Ellakkis ${ }^{2}$ Elton Gomes Silva ${ }^{1,2}$ \\ Edgar Manuel Garcete Farina ${ }^{20}$ Raymond Assad El Sarraf ${ }^{20}$
}

${ }^{1}$ Medicine Course, Instituto latino americano de Ciências da Vida e da
Natureza (ILACVN) Universidade Federal da Integração Latino
Americana, Foz do Iguaçu, PR, Brazil
${ }^{2}$ Hospital Municipal Padre Germano Lauck, Foz do Iguaçu, Brazil

Address for correspondence Paulo Lucas Capelini Frisso, Universidade Federal da Integração Latino Americana, Foz do Iguaçu, Brasil (e-mail: plc.frisso.2016@unila.edu.br).

Arq Bras Neurocir 2021;40(2):e162-e166.

\begin{abstract}
Keywords

- cerebral abscess

- dental infection

- Streptoccocus intermedius
\end{abstract}

\section{Resumo}

received

September 2, 2020

accepted

November 16, 2020

published online

March 29, 2021
Introduction Cerebral abscess is a suppurative infection of the cerebral parenchyma, which may occur due to contiguity, hematogenous dissemination of distant foci, secondary to open traumatic brain injuries, or be idiopathic.

Clinical Case A 63-year-old male patient sought assistance due to a severe headache in the frontal region associated with chills and lack of appetite that started four days before. Clinical examination of the patient showed no significant changes. Imaging and laboratory tests on admission showed only nonspecific changes, such as leukocytes 18,540 , platelets 517,000 , and c-reactive protein 2,0 . In such case, magnetic resonance imaging (MRI) of the skull was performed with contrast, showing the presence of expansive lesions compatible with multiple brain abscesses in the right parietooccipital region.

Discussion After excluding the main focus of hematogenous dissemination and in view of the identification of the agent Streptococcus intermedius by means of secretion culture collected through a surgical method, the hypothesis of abscess due to contiguous dental pyogenic foci was pointed out.

Conclusion Dental evaluation showed multiple foci of infection with periodontitis and dental abscess, which were treated along with the use of antibiotics directed to the etiologic agent.

Abcesso cerebral é uma infecção supurativa do parênquima cerebral, podendo ocorrer por contiguidade, disseminação hematogênica de foco a distância, secundário a traumas cranioencefálicos abertos ou ser idiopático. Caso clínico: Paciente do sexo masculino, 63 anos, procura atendimento devido a queixa de cefaleia intensa com início há quatro dias. Exame de imagem realizado evidencia lesãos expansivas

March 29.2021

DOI https://doi.org/ 10.1055/s-0040-1722242. ISSN 0103-5355.

\footnotetext{
c 2021. Sociedade Brasileira de Neurocirurgia. All rights reserved. This is an open access article published by Thieme under the terms of the Creative Commons Attribution-NonDerivative-NonCommercial-License, permitting copying and reproduction so long as the original work is given appropriate credit. Contents may not be used for commercial purposes, or adapted, remixed, transformed or built upon. (https://creativecommons.org/ licenses/by-nc-nd/4.0/) Thieme Revinter Publicações Ltda., Rua do Matoso 170, Rio de Janeiro, RJ, CEP 20270-135, Brazil
} 
Palavras-chave

- abcesso cerebral

- infecção odontológica

- Streptoccocus intermedius compatíveis com abscessos cerebrais múltiplos na região parieto-occipital a direita. Discussão: Após a exclusão dos principais focos de disseminação hematogênica e diante da identificação do agente Streptococcus intermedius por meio de cultura de secreção coletado por método cirúrgico, foi levantada a hipótese de abscesso por contiguidade de foco piogênico dentário. A avaliação odontológica evidenciou múltiplos focos infecciosos com periodontite e abscesso dentário, que foram tratados conjuntamente com o uso de antibiótico direcionado para o agente etiológico.

\section{Introduction}

Cerebral abscess is a suppurative infection that affects the cerebral parenchyma. ${ }^{1}$ It is the second most common purulent infection in the immunocompetent central nervous system (CNS), followed only by bacterial meningitis. ${ }^{2}$ Parenchyma involvement can occur due to contiguous infection mechanisms (between 40 and $50 \%$ of cases), hematogenous dissemination of distant focus (25\% of cases), secondary to open traumatic brain injuries ( $10 \%$ of cases) or idiopathic (15\% of cases). ${ }^{3,4}$

In most cases, the etiologic agent is of bacterial origin; however, it should be noted that these can also occur via other microorganisms, such as protozoa or fungi. ${ }^{5}$ The microbiological agent involved in the genesis of the abscess depends on how it is inoculated into the brain tissue. Furthermore, abscesses that occur due to contiguous infection are usually caused by infections in nearby regions, such as otitis, mastoiditis, sinusitis, periodontal disease, among others. ${ }^{6-8}$ Among the most common pathogens are: Staphylococcus aureus, Streptococcus sp, Haemophylos influenzae, Bacteroides and Peptostreptococcus. ${ }^{4,6}$

Abscesses related to dental infections typically have polymicrobial derivation, highlighting the streptococci, staphylococci species, Actinomyces sp, Actinobacillus sp, Fusobacterium sp. ${ }^{9}$ Secondary spreads to otitis, mastoiditis or sinusitis are more related to streptococcal (especially Streptococcus pneumoniae), Enterobacteriaceae, S. aureus and some anaerobes such as Prevotella sp., Bacteroides sp. ${ }^{1}$ Abscesses caused by otitis and/or mastoiditis have a greater coefficient of temporal lobe and cerebellum infection, while the secondary to rhinosinusitis or periodontal infection most commonly affect the frontal lobe. ${ }^{2,4,10}$ In addition, abscesses originating from hematogenous dissemination are usually multiple and tend to affect, predominantly, regions irrigated by the middle brain (posterior frontal lobe and parietal lobe). 2,3,10

In relation to the most common focus of hematogenous dissemination, it could be mentioned: infective endocarditis, cardiac alterations such as tetralogy of Fallot, patent foramen ovale, cyanotic heart disease; lung abscess or bronchiectasis. ${ }^{2,3,10}$ The foci of the spread of infectious endocarditis are often related to $S$. Aureus, species of streptococcus and bacteria of the HACEK group (Haemophilus spp, Actinobacillus actinomycetemcomitans, Cardiobacterium hominis, Eikenella corrodens and Kingella kingae). ${ }^{1}$ Infections of pulmonary dissemination focus or heart diseases that involve formation of arteriovenous shunts are generally polymicrobial, and involve streptococcus, anaerobic species (Actinomyces sp., Prevotella sp., Bacteroides sp., Fusobacterium sp), staphylococci and Enterobacteriaceae ${ }^{1,10}$.

Infections linked to neurosurgical procedures due to nosocomial infections have Meticycline-resistant S. Aureus as its main cause, but other species such as propionibacterium and coagulase-negative staphylococcus may also be involved. ${ }^{4,10}$ In trauma-related abscesses, it is known that Cranioencephalic S. Aureus is the main agent. ${ }^{4,11}$

\section{Objective}

To report a clinical case to identify the etiology and other cause and effect relationships involved in the genesis of a rare case of brain abscess.

To analyze the diagnostic approach performed and correlate it with the main current diagnostic protocols.

\section{Clinical Case Report}

\section{Anamnesis}

A 63-year-old male patient sought assistance due to complaints of low back pain and severe headache. He reported that 4 days before he presented with severe headache in the frontal region, associated with chills and lack of appetite. He sought care at the local Emergency Unit, where he received symptomatic medication, resulting in partial improvement of symptoms. He also reported that 24 hours before he noticed the onset of pain in the lumbar region, of the prick type, associated with paresis in the lower limbs and partial paresthesia in sporadic moments.

General physical examination did not show any particularity and, at the neurological examination, he was bedridden, with no signs of meningeal irritation, with muscle strength and reduced tactile sensitivity in the left lower limb.

Laboratory admission tests were requested, namely: Leukocytes 18,540 without deviation presence of rods, platelets 517,000 , urea 54 , creatinine 0.9 , sodium 140 , potassium 4.5 , lactate 17.20 , ionic calcium 1.2 , magnesium 2 , 3, c-reactive protein 2, urine test unchanged. Simple chest radiographs did not show any significant changes. In such case, magnetic resonance imaging (MRI) of the skull was performed with contrast (-Fig. 1).

After referral to blood cultures and echocardiography, to rule out possible foci of hematogenous dissemination, no 


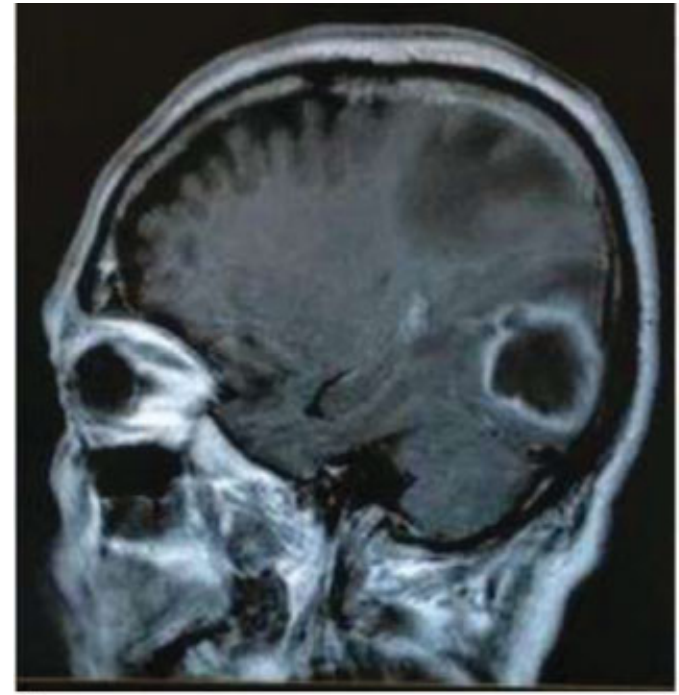

A

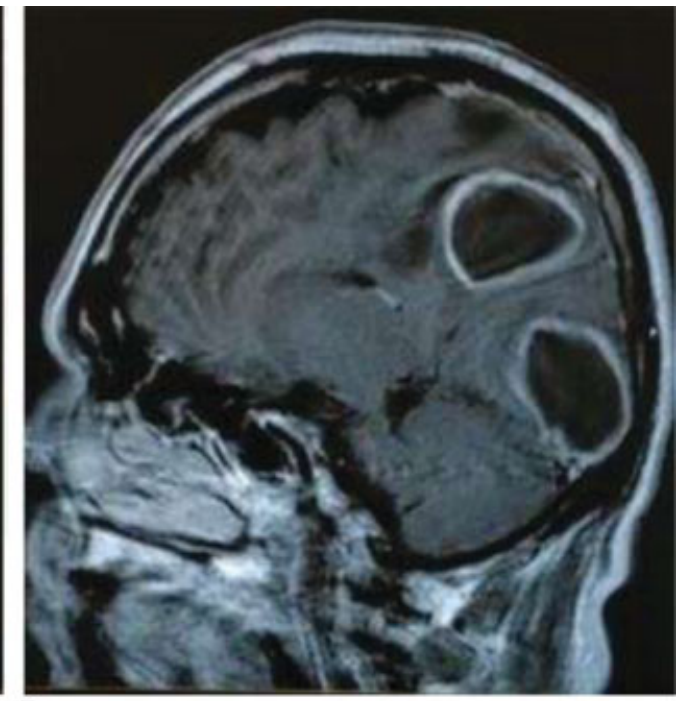

$\mathbf{B}$

Fig. 1 Shows the magnetic resonance of the skull, performed with the patient under discussion, showing expansive lesions compatible with multiple brain abscesses. Source: The authors (2020).

underlying changes were demonstrated. Then, antibiotic therapy with ceftriaxone and metronidazole was started.

Seven days after admission, the patient showed an evolution with a lower level of consciousness, requiring orotracheal intubation and urgent surgery. Therefore, craniotomy was performed to remove cystic lesions, with the collection of material for culture. Six days after the surgery, the secretion culture followed, positive for Streptococcus intermedius. In view of the identified etiologic agent, an oral and maxillofacial surgeon evaluation was requested, since the existence of signs of gingivitis with severe periodontitis and dental abscess in two teeth was confirmed, associated with mucositis in the soft structures. Finally, the region was cleaned, in addition to maintaining the use of intravenous antibiotics for 21 days.

\section{Discussion}

When facing a patient with a headache complaint, the first step is to identify whether this is a primary or secondary disorder. ${ }^{12}$ Primary headaches refer to chronic and continuous disorders of a dysfunctional nature, not involving anatomical or structural changes, ${ }^{13}$ while secondary headaches are symptoms of an underlying, neurological or systemic disease (meningitis, brain tumor, among others). ${ }^{14}$

The main premonitory for identifying a secondary headache is the presence of alarm signs: change in the pattern of pre-existing headache, progressive intensity headache, sudden onset, associated focal neurological deficit, decreased level of consciousness, seizure, systemic manifestations (fever, toxemia, immunodepression, skin rash), beginning after 50 years of age. ${ }^{12,14}$ It is evident that, in the face of a headache with alarm signs, it is necessary to use imaging exams for better diagnostic clarification, with computed tomography (CT) being the exam of choice. ${ }^{12}$

The patient presented several alarming signs that indicated it was a secondary headache: sudden onset, progressive intensity, onset after 50 years of age, focal neurological deficit (reduced strength in the left lower limb), signs of toxemia with fever and chills. As for the other clinical manifestations, here we show all three classic manifestations of brain abscesses: headache, fever and focal neurological deficit.

Initially, a CT scan of the skull was performed. However, it became necessary to perform an MRI to better assess the lesion. This last examination showed multiple brain abscesses in the parieto-occipital region. As reviewed, multiple abscesses are more common in hematogenous foci, and tend to occur in the middle cerebral artery supply region, predominating in the posterior region of the frontal lobe and in the anterior region of the parietal lobe. Foci of hematogenous dissemination to the occipital lobe may occur, but are less common.

Under suspicion of hematogenous dissemination, it is mandatory to find the primary focus. The most common focus of hematogenous dissemination are endocarditis, cardiovascular malformations and pyogenic lung infections. The complete absence of pulmonary symptomatology, associated with an admission-free X-ray of the chest, practically rules out the latter form of dissemination, resting the hypotheses in the probable cardiac focus. The echocardiogram is the exam of choice for the assessment of endocarditis or cardiac structural changes. In this case, the echocardiogram showed no changes, making it necessary to investigate further to find the primary focus of the infection.

While the specific agent is not identified, the guidelines indicate the beginning of empirical antibiotic therapy. Third and fourth cephalosporins generation are the first choice for coverage of gram positive and gram negative germs, while the combination with metronidazole provides adequate coverage against anaerobic germs. It is a given fact that the choice of antibiotic therapy in this case, performed with ceftriaxone and metronidazole, was appropriate.

After surgical removal and material collection, the culture showed the etiologic agent involved in the infection of 
the parenchyma: S. intermedius. This agent is a highly positive, facultative anaerobic bacterium that is part of the commensal flora of the oropharynx and gastrointestinal tract. Their involvement in polymicrobial and suppurative infections is common. ${ }^{15}$ Faced with an infection by a common agent in the oral mucosa, the hypotheses now fall on a probable odontogenic spread.

The evaluation of the oral health team showed multiple foci of oral infection, with the presence of severe periodontitis and dental abscess. Periodontitis is a chronic inflammatory process of bacterial etiology, which affects a dental structure (connective tissue, periodontal fiber and bones). ${ }^{16,17}$ The most common etiological agents associated with periodontitis are Aggregatibacter actinomycetamcomitans and Porphyromonas gingivalis species. $^{16}$

Streptococcus is the group of bacteria most related to oral diseases. ${ }^{18}$ Some species such as Streptoccocus mutans are related to the occurrence of dental caries, while S. Intermedius and Streptoccocus constellatus usually colonize dental biofilm in patients with untreated chronic periodontitis. ${ }^{18,19}$ The colonization of previous periodontal foci by bacteria of the species S. Intermedius and S. constellatus exacerbate the initial infectious process, which can trigger tooth loss and pyogenic complications such as brain abscess, liver abscess and bacteremia. $^{19-21}$ Despite being part of the normal flora of the oropharyngeal, genitourinary and gastrointestinal tracts, evidence of reports of involvement of these species in purulent infections such as brain and liver abscesses, as well as the occurrence of bacteremia caused by S. Intermedius after dental manipulation, even without the presence of an infectious process active gingival. $^{20-22}$

The finding of a common bacterium of the oral flora in the culture of the abscess, associated with several foci of dental infection liable to spread, reinforces the hypothesis that this abscess was caused by contiguous infection from these multiple odontogenic foci.

\section{Final Considerations}

The reported case was a rare case of cerebral abscess secondary to odontogenic infection. In agreement with the literature, abscesses caused by the spread of contiguous foci tend to be single abscesses, keeping a close relationship between the dissemination focus and the location of the abscess formation. Furthermore, this type of case affects the frontal lobe, and rarely causes multiple abscesses.

We can conclude from the consultation of the literature and the report of the case presented that it is not common for odontogenic infections to complicate with the formation of abscesses in the parieto-occipital region, even more so with multiple involvement. The immediate treatment of the abscess and its source with multidisciplinary care allows the full recovery of the patient.

Conflict of Interests

The authors have no conflict of interests to declare.

\section{References}

1 Cantiera M, Tattevin P, Sonneville R. Brain abscess in immunocompetent adult patients. Rev Neurol (Paris) 2019;175(78):469-474

2 Pittella JEH, Rosemberg S, Hahn MD, et al. Sistema Nervoso. In: Filho GB. Bogliolo Patologia. 9th rev. ed. Guanabara Koogan; 2016. 26; 1253-1442

3 Junior EBP, Coelho MDG, Parente TMCM, Coutinho OMV, Alves ON. Abordagem terapêutica de abscessos cerebrais múltiplos de causa idiopática em paciente imunocompetente: relato de caso. Revista de Patologia do Tocantins. 2018;5(04):23-27

4 Sveinsson OA, Ásgeirsson H, Ólafsson IH. [Brain abscess - overview]. Laeknabladid 2013;99(01):25-31

5 Darlow CA, McGlashan N, Kerr R, et al. Microbial aetiology of brain abscess in a UK cohort: Prominent role of Streptococcus intermedius. J Infect 2020;80(06):623-629

6 Correia FCS, Gonçalves PPF, Martins AL, Tauil VMA, Marinho MF, Reis CHM. Abcesso cerebral secundário á rinossinusite bacteriana: um relato de caso. Saber digital [Internet] 2017 [cited 2020 Jul 12];p. 11-19. Available from: http://revistas.faa.edu.br/index.php/SaberDigital/article/view/273

7 Frosch MP, Anthony DC, Girolami UD, Kumar V, Abbas Ak, Fausto $\mathrm{N}$, Aster Jc. O sistema nervoso. In: Robbins e Cotran Bases patológicas das doenças. 8th ed. Rio de Janeiro: Elsevier; 2010. 28, 1279-1344

8 Oliveira RL, Raffaele RM, Baldo ME, Jardim ECG. Abscesso cerebral e infecção odontogênica. Rev Bras Ter Intensiva 2020;32(01): 161-162

9 Kichenbrand C, Marchal A, Mouraret A, et al. Brain abscesses and intracranial empyema due to dental pathogens: Case series. Int J Surg Case Rep 2020;69:35-38. Doi: 10.1016/j.ijscr.2020.03.025

10 Roos KL, Tyler KL. Meningite, encefalite, abscesso cerebral e empiema. In: Kasper DL, et al. Harrison Medicina Interna, v.2. 19a. Edição. Rio de Janeiro: McGrawHill; 2017:3892-3910

11 Nath A, Berger J. Brain Abscess and parameningeal infections. In: Goldman L, Schafer A. Goldman Cecil Medicine - 2 Vols. - $24^{\mathrm{a}}$ Ed. 2014Editora Elsevier; 2731-2736

12 Souza MNP. Cefaleia In Velasco IT, Brandão Neto RA, Souza HP de, Marino LO, Marchini JFM, Alencar JCG de. Medicina de emergência: abordagem prática 13a edição. Editora Manole; 2019: 317-325

13 UFSC. Eventos agudos na atenção básica: Cefaleia. Universidade Federal de Santa Catarina Campus Universitário, 88040-900 Trindade [Internet]. 2013 [cited 2020 Jul 12]; Available from: www.unasus.ufsc.br

14 Speciali JG, Kowacs F, Jurno ME, et al. Protocolo nacional para diagnóstico e manejo das cefaleias nas unidades de urgência no Brasil: Cefaleia. Academia Brasileira de Neurologia - Departamento Científico de Cefaleia Sociedade Brasileira de Cefaleia [Internet] 2018 [cited 2020 Jul 12]; Available from: https:// sbcefaleia.com.br/images/file\%205.pdf

15 Matos de FC, Susana P, Anabela B, Ana R, Fernando G, Lurdes M. Infeção invasiva por Streptococcus intermedius: quando um agente comensal pode ser patogénico. Nascer Crescer 2014;23 (Suppl 3):30-30

16 Manresa C, Sanz-Miralles EC, Twigg J, Bravo M. Supportive periodontal therapy (SPT) for maintaining the dentition in adults treated for periodontitis. Cochrane Database Syst Rev 2018;1(01): CD009376. Doi: 10.1002/14651858.CD009376.pub2

17 Mombelli A, Walter C. Antibiotikarichtlinien Parodontologie. [Antibiotics in Periodontics]. Swiss Dent J 2019;129(10):835-838

18 Phumat P, Khongkhunthian S, Wanachantararak P, Okonogi S. Effects of Piper betle fractionated extracts on inhibition of Streptococcus mutans and Streptococcus intermedius. Drug Discov Ther 2018;12(03):133-141. Doi: 10.5582/ddt.2018.01021

19 Rams TE, Feik D, Mortensen JE, Degener JE, van Winkelhoff AJ. Antibiotic susceptibility of periodontal Streptococcus constellatus 


\section{Multiple Brain Abscesses Secondary to Odontogenic Infection Frisso et al.}

and Streptococcus intermedius clinical isolates. J Periodontol 2014; 85(12):1792-1798. Doi: 10.1902/jop.2014.130291

20 Livingston LV, Perez-Colon E. Streptococcus intermedius Bacteremia and Liver Abscess following a Routine Dental Cleaning. Case Rep Infect Dis 2014;2014:954046. Doi: 10.1155/2014/954046

21 Hasegawa N, Sekizuka T, Sugi Y, et al. Characterization of the Pathogenicity of Streptococcus intermedius TYG1620 Isolated from a Human Brain Abscess Based on the Complete Genome
Sequence with Transcriptome Analysis and Transposon Mutagenesis in a Murine Subcutaneous Abscess Model. Infect Immun 2017;85(02):e00886-e16. Doi: 10.1128/IAI.00886-16

22 Vargas López AJ, Galicia Bulnes JM, Al Ghanem Ghanem R, El Rubaidi Abdullah O. Streptococcus intermedius posterior fossa abscess after a minor dental procedure in an immunocompetent woman. Neurocirugia (Astur) 2019;30(06):305-308 